\title{
Meloidogyne arenaria attacking eggplant in Souss region, Morocco
}

\author{
Fouad Mokrini ${ }^{1}$ (D) - Ali El Aimani ${ }^{2} \cdot$ Abdellah Houari $^{3} \cdot$ Rachid Bouharroud $^{1}$. \\ Ahmed Wifaya ${ }^{1} \cdot$ Abdelfattah A. Dababat $^{3,4}$
}

Received: 13 March 2019 / Accepted: 12 August 2019 / Published online: 28 August 2019

(C) Australasian Plant Pathology Society Inc. 2019

\begin{abstract}
Root-knot nematodes extracted from eggplant (Solanum melongena cv. Black beauty) root samples collected from plantations in the Souss region of Morocco, was identified as Meloidogyne arenaria based on female perineal pattern and sequencecharacterized amplified region polymerase chain reaction (SCAR-PCR) technique.
\end{abstract}

Keywords Eggplants · Galls $\cdot$ Identification

Meloidogyne spp. are the most damaging plant-parasitic nematodes in vegetable production (Jones et al. 2013). In Morocco, nematode species of the genus Meloidogyne are among the most relevant group of plant parasitic nematodes and are widely distributed throughout the country (Mokrini 2016; Janati et al. 2018). Both Meloidogyne javanica and $M$. incognita are the most common species in different agricultural areas of Morocco (Janati et al. 2018). In June 2016, eggplants (Solanum melongena cv. Black beauty) with aboveground symptoms of stunting and leaf wilting were recorded in a field in the Souss region of Morocco (Latitude: 30.320739; Longitude: -9.482632). Examination of the root samples taken from plants showing above-ground symptoms revealed the presence of root-knot nematodes (galls) (Fig. 1). Egg masses $(n=4)$ were picked up individually from infested roots using a small needle. These egg masses were surfacesterilized in $0.5 \% \mathrm{NaOCl}$ as described by Dababat and Sikora

Fouad Mokrini

fmorknini.inra@gmail.com

1 Biotechnology Research Unit, National Institute of Agricultural Research (INRA), Rabat, Morocco

2 Syngenta, Crop Protection Development Rabat, Rabat, Morocco

3 Taroudant Multidisciplinary Faculty, Laboratoire de Biotechnologie, Valorisation et Envirennement, Rabat, Morocco

4 International Maize and Wheat Improvement Center (CIMMYT), Emek, Ankara, Turkey
(2007) then rinsed in tap water 3 times and prepared for inoculation. To obtain pure cultures, seedlings of susceptible tomato plant (Solanum lycopersicum, cv. Prystila F1) were transplanted singly into $500 \mathrm{~mL}$ plastic pots containing sterilized sandy loam soil and sand $(2: 1, v / v)$ and were allowed to grow for 5-7 days before each was inoculated with a single egg mass. Plants were maintained in a glasshouse at temperature rate of $25 \pm 5^{\circ} \mathrm{C}$, artificial light of $16 \mathrm{~h}$ per day, and 60 to $90 \%$ of relative humidity. Sixty days after inoculation, plants were removed from pots, root systems were gently washed to free of adhering soil particles, and adult females were recovered from roots with a fine needle. The collected adult females were identified by the female perineal pattern, and by sequence-characterized amplified region polymerase chain reaction (SCAR-PCR) technique as Meloidogyne arenaria. Female $(n=20)$ perineal patterns had the characteristic rounded to flattened, low dorsal arch, sometimes flat with dorsal striae abruptly to the lateral field and forming a small shoulder (Fig. 2). Measurements and morphological observations of $20 \mathrm{~s}$-stage juveniles $(\mathrm{J} 2 \mathrm{~s})$ were: body length $=435 \pm$ $18.4 \mu \mathrm{m}$; stylet length $=10.1 \pm 0.9 \mu \mathrm{m} ; \mathrm{DGO}=2.6 \pm$ $0.5 \mu \mathrm{m}$; tail length $51 \pm 1.2 \mu \mathrm{m}$; hyaline tail terminus $=9.1$ $\pm 1.1 \mu \mathrm{m}$. The morphology and morphometry of this species conformed with descriptions and measurements provided by Hunt and Handoo (2009). Microscope slides of M. arenaria perineal patterns were deposited at the Nematology laboratory at National Institute of Agricultural Research (INRA), Agadir, Morocco, with the following accession numbers: MF322019, MF332019, and MF342019. From each morphologically investigated female, DNA was extracted from single J2 $(n=4)$ by incubating them in a lysis buffer $(200 \mathrm{mM} \mathrm{NaCl}, 200 \mathrm{mM}$ 


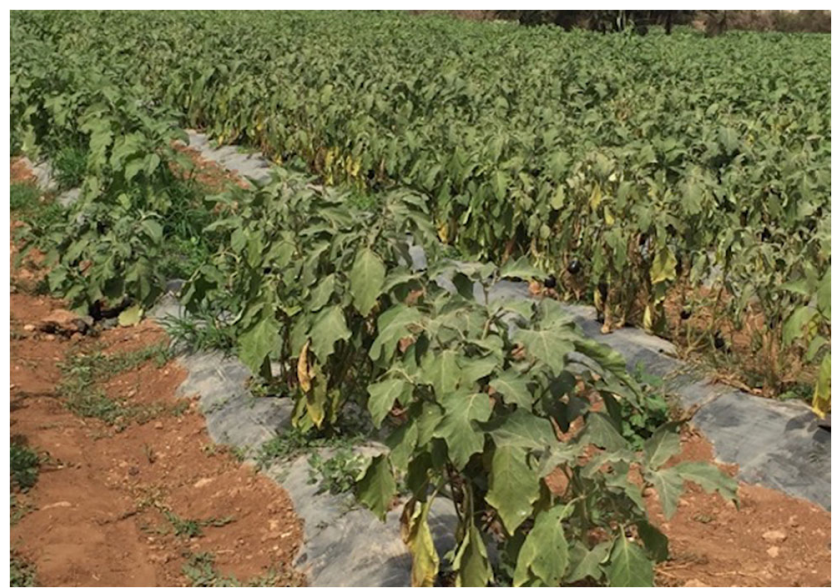

Fig. 1 Eggplant fields in Kliaa with above-ground symptoms of stunting and leaf wilting

Tris- $\mathrm{HCl}(\mathrm{pH} \mathrm{8)}, 1 \%$ ß-mercaptoethanol and $800 \mu \mathrm{g} / \mathrm{ml}$ Proteinase K) for $1.5 \mathrm{~h}$ at $65{ }^{\circ} \mathrm{C}$ and $5 \mathrm{~min}$ at $99{ }^{\circ} \mathrm{C}$ in a thermocycler. One $\mu \mathrm{L}$ of crude DNA extract was used for PCR. The juveniles' DNA was amplified via PCR using primers Far (5'-TCGGCGATAGAGGTAAATGAC-3') and Rar (5'-TCGGCGATAGACACTACAACT-3'), which are specific for amplification of Meloidogyne arenaria (Zijlstra et al. 2000). The amplified PCR product was run on a $1 \%$ agarose gel, and a 420-bp fragment was observed under an ultraviolet light (Fig. 3), confirming the population to be M. arenaria (Zijlstra et al. 2000). The pathogenicity test was conducted under greenhouse condition at an average temperature of $25^{\circ} \mathrm{C}$. Seedlings $(n=10)$ of eggplant were maintained in pots (12 cm high and $8 \mathrm{~cm}$ diam) filled with sterilized sand and subsequently each plant was inoculated with a suspension of 1000 eggs and $\mathrm{J} 2 \mathrm{~s}$ obtained from the pure single egg mass culture of the original $M$. arenaria population. Pots of non-

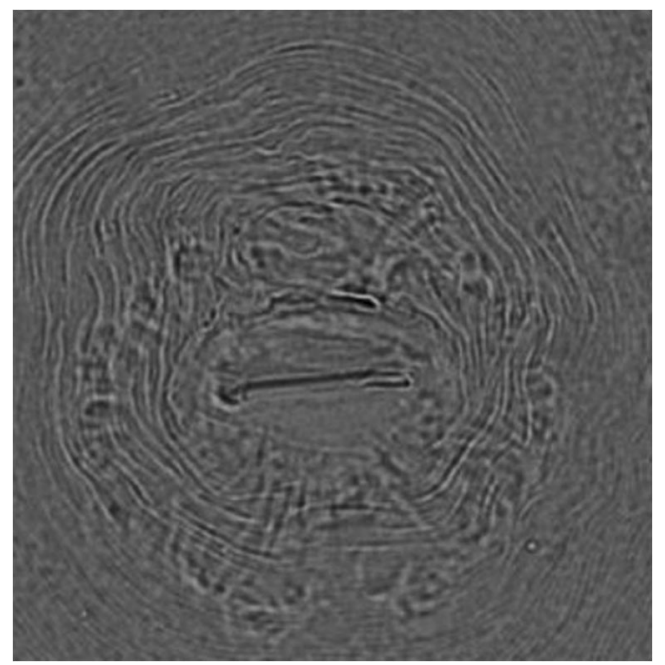

Fig. 2 Perineal patterns for Meloidogyne arenaria collected from eggplant roots in Souss region of Morocco

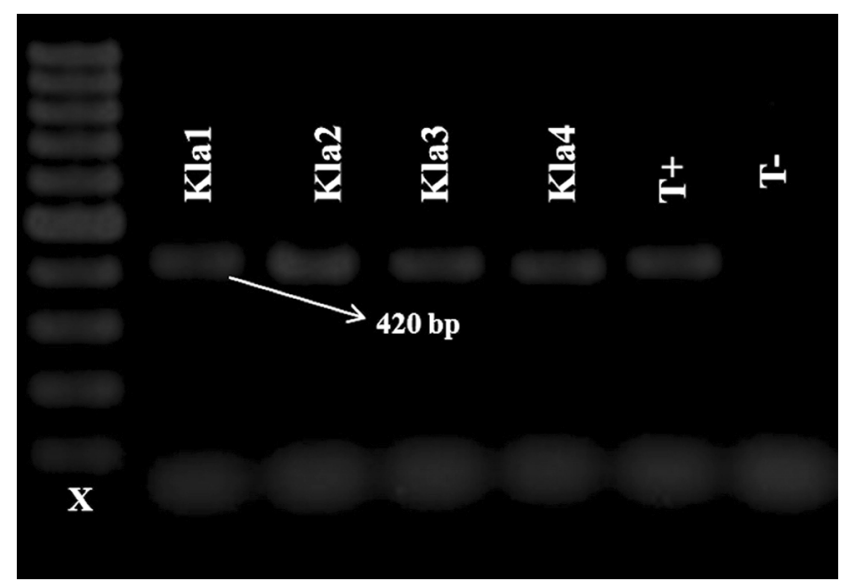

Fig. 3 Amplification product (420 bp) with Far/Rar primers on Meloidogyne population from the Souss region of Morocco. $X=100 \mathrm{bp}$ DNA ladder; Tnegative control; $\mathrm{T}+$ : positive control (obtained from Turkey)

inoculated seedlings served as controls $(n=8)$. Seventy days after inoculation, plants were uprooted and roots were galled similarly to plants encountered in the field. Nematode eggs were extracted from tomato roots by cutting the entire root system into approximately $2.5-\mathrm{cm}$ pieces, placing the pieces in a 1.5-1 flask, and agitating for $4 \mathrm{~min}$ in a $1 \% \mathrm{NaOCl}$ (Hussey and Barker 1973). Eggs were collected and rinsed with tap water on nested 75 - and $25-\mu \mathrm{m}$-pore sieves and counted. Nematode population densities were in the ranges of 2256 to 4234 eggs per $10 \mathrm{~g}$ of root. The reproduction factor (final nematode population/initial population) was 6.4, demonstrating this species multiply on this host. The nematodes were re-extracted from plant tissue and identified as aforementioned. No symptoms were observed on control plants. Further studies on root-knot nematodes in the Souss region will be necessary to determine whether there are other species of nematodes causing damage to eggplant, to assess crop losses and to develop effective control and management strategies in the region.

\section{References}

Dababat AA, Sikora RA (2007) Influence of the mutualistic endophyte, Fusarium oxysporum 162 on Meloidogyne incognita attraction and invasion. Nematology 9(6):771-776. https://doi.org/10.1163/ 156854107782331225

Hunt DJ, Handoo ZA (2009) Taxonomy, identification and principal species. In: Perry RN, Moens M, Starr JL (eds) Root-Knot Nematodes. CABI, Wallingford, pp 55-97

Hussey RS, Barker KR (1973) Comparison of methods for collecting inocula of Meloidogyne spp., including a new technique. Plant Dis Rep 57:1025-1028

Janati S, Houari A, Wifaya A, Essarioui A, Mimouni A, Hormatallah A, Sbaghi M, Dababat AA, Mokrini F (2018) Occurrence of the rootknot nematode species in vegetable crops in Souss region of Morocco. Plant Pathol J 34:308-315. https://doi.org/10.5423/PPJ. OA.02.2018.0017 
Jones JT, Hagemain A, Danchin EGJ, Gaur HS, Helder J, Jones MGK, Kikuchi T, Manzanilla-Lopez R, Palomares-Rius JE, Wesemael WML, Perry RN (2013) Top 10 plant-parasitic nematodes in molecular plant pathology. Mol Plant Pathol 14:946-961

Mokrini F (2016) Les nématodes de la tomate dans le Souss-Massa. Agri Mag 93:54-57
Zijlstra C, Donkers-Venne DTHM, Fargette M (2000) Identification of Meloidogyne incognita, M. javanica and $M$. arenaria using sequence characterised amplified region (SCAR) based PCR assays. Nematology 2:847-853. https://doi.org/10.1163/ 156854100750112798 